\title{
IMPROVEMENT OF ARABIC LANGUAGE TEACHER COMPETENCY BASED ON MULTIPLE INTELLIGENCE CLASSROOM
}

\author{
Janniarni Toha Safutri \\ e-mail: utyjanniarni@gmail.com \\ Universitas Islam Negeri Maulana Malik Ibrahim Malang \\ Suci Ramadhanti Febriani \\ e-mail: suciramadhantifebriani11@gmail.com \\ Universitas Islam Negeri Maulana Malik Ibrahim Malang \\ Danial Hilmi \\ e-mail: danialhilmi@gmail.com \\ Universitas Islam Negeri Maulana Malik Ibrahim Malang
}

\begin{abstract}
This research aims to determine the efforts made in improving the competence of Arabic teacher through multiple intelligence-based classroom management at SD Plus Al-Kautsar Malang. It used a qualitative approach with a case study research design. The data collection included observation, interviews, and documentation, while analysis techniques relied on Miles and Hubermen' steps as follow; data reduction, data display, and conclusion. The results showed that the efforts to increase the competency of Arabic teachers through multiple intelligence-based classroom management at SD Plus AlKautsar Malang, including the improvement of pedagogic and professional competences. The effort to increase pedagogic competence was giving the training to educators related to the design of a lesson plan, while the effort to increase professional competence is training in applying multiple intelligence during the learning process, such as Multiple Intelligence System (MIS) and Multiple Intelligence Research (MIR) training.
\end{abstract}

Keywords: Teacher competency, classroom management, Arabic language, multiple intelligences.

\begin{abstract}
Abstrak: Penelitian ini bertujuan untuk menganalisis upaya yang dilakukan dalam meningkatkan kompetensi guru bahasa Arab melalui manajemen kelas berbasis multiple intelligences di SD Plus Al-Kautsar Malang. Penelitian ini menggunakan pendekatan kualitatif dengan metode studi kasus. Teknik pengumpulan data meliputi observasi, wawancara, dan studi dokumentasi, sedangkan teknik analisis data menggunakan langkahlangkah analisis Miles dan Hubermen sebagai berikut; reduksi data, penyajian data, dan penarikan kesimpulan. Hasil penelitian ini menunjukkan bahwa upaya peningkatan kompetensi guru bahasa Arab melalui manajemen kelas berbasis kecerdasan majemuk di SD
\end{abstract}

56 |Janniarni Toha Safutri, Suci Ramadhanti Febriani, Danial Hilmi 
Plus Al-Kautsar Malang meliputipeningkatan kompetensi pedagogik dan profesional. Upaya peningkatan kompetensi pedagogik yaitu diberikannya pelatihan kepada guru terkait pembuatan RPP, sedangkan upaya peningkatan kompetensi profesional yaitu pelatihan penerapan multiple intelligence ketika proses pembelajaran, seperti pelatiban Multiple Intelligence System (MIS) dan Multiple Intelligence Research (MIR).

Kata Kunci: Kompetensi guru, manajemen kelas, bahasa Arab, kecerdasan majemuk.

\section{INTRODUCTION}

Based on Law Number 14 year 2005 on Teachers and Lecturers (2005: 35), pedagogic competence, personality competence, social competence, and professional competence are four very urgent things to create professional, nationally certified, and internationally standardized teachers. This is in accordance with UNESCO's appeal that, in 2030, all nations incorporated in the United Nations (UN) must have a standardized teacher quality.

Ideally, teachers who have standardized qualities as according to Sembiring (2009:3637), namely: 1) Teachers must be well educated. This is evident, that teachers are obliged to have academic qualifications, competence, and certificate of educators. 2) The teacher must be well trained. Teachers must ever and have access through a series of education and training to be professional. Training includes the provision of educational academic education programs, in order to obtain academic qualifications. There is also a professional skills formation program to get provision in the competency test which leads to the acquisition of teacher profession certification. 3) The teacher must have a good appreciation. As with perks, ranging from functional benefits to professional benefits. 4) The teacher must be well protected. If the three criteria above is fulfilled it will be wasted if it does not get protection as it should be according to the profession demands. So there must be a guarantee of legal certainty protecting the rights and obligations of educators. 5) The teacher must be well managed. Educators can't by itself govern all things on their own. There must be a well- managed arrangement with various criteria, procedures, timeframes, mechanisms, and accountability in procurement or placement as well as in rotation or promotion. There must be also increased qualifications and professional education efforts included in the framework of competency testing.

Judging from the criteria of the above, ideal teacher is seen that the profession of teachers is a fairly complex profession and can't be arbitrary. Being a teacher is not enough with enough lectures and academics, but also have to keep practicing so have experience and know what to do.

Graduate of SD Plus Al-Kautsar Malang is an integral part of the existence of educational institutions. The majority alumni of SD Plus Al-Kautsar Malang continue their education in some of the best schools in Malang. SD Plus Al-Kautsar Malang is among the formal education of the basic education level that is a pioneer of multiple intelligences school which accept students in diverse cognitive conditions instead of the best input. Therefore, the success of the graduate SD Plus Al-Kautsar Malang is very determined by the competence that the teachers have, such as understanding students psychologically.

Based on the results of Trilling and Fadel studies, cited by Zubaidah (2016), elementary, secondary, diploma and higher education graduates are still less competence in the following matters; (1) Oral and written communication, (2) critical thinking and addressing problems, (3) working ethic and professionalism, (4) working in teams and 
collaborating, (5) working in different groups, (6) using technology, and (7) project management and Leadership. Whereas if we refer to various references that there are very needed skills in this $21^{\text {st }}$ century because of the flow of globalization that increasingly blurring the country boundaries. In these conditions, one of the most important skills to master learners is the verbal and written foreign language skills. In terms of language learning, the results of the Trilling and Fadel study are evidence that language learning should be of serious attention, especially for teachers ' attention.

Meanwhile, the report Badan Standar Nasional Pendidikan (BSNP) (2011: 27) mentions that the purpose of national education XXI century, "should be to realize the ideals of the nation, which is the prosperous and happy people of Indonesia, with a respectable and equal position with the nation Other in the global world, through the establishment of a community consisting of qualified human resources, namely self-reliant, skilled and capable to realize the ideals of its people ". Based on that, the BSNP emphasizes that learning in the XXI century should be able to increase the competence of learners at a high level and independently with indications students can think critically and creatively. Then, that students can think critically and creatively, not regardless of the role of teachers.

Based on the observation, some of the Arabic teachers teach at SD Plus Al-Kautsar Malang are not graduates of the Arabic language education, but rather from the Qur'an teacher and hadith commentary, which causes the effort to improve the competence of the teachers. Classroom management based on multiple intelliegence in Arabic learning that demands the teachers to improve teaching competence in accordance with the intelligence of students.

Based on factual data, the researchers are interested to know the effort done by SD Plus Al-Kautsar Malang in improving the competence of Arabic teachers through classroom management based on multiple intelligence. Previous research by Ulfah Sifti Rahmawati related to "teacher competence in developing multiple intelligence students" shows that teacher competence in learning can influence the level of learners' understanding of the material. The competency of teachers who must be owned by an educator is the pedagogic competence, professional competence, personality competence, and social competence. Each individual has different characteristics (multiple intelligences), then learning for learners should vary according to the ability and potential of each student to make the learning more meaningful. So, this research, has a renewal side of previous research that is focus on the efforts conducted by SD Plus Al-Kautsar Malang in improving the competence of Arabic language teachers through the management classroom based on multiple intelligences.

The urgency of this research done is to know the effort done by SD Plus AlKautsar Malang in improving the competence of Arabic language teachers through the management of multiple-based class intelligences.

\section{RESEARCH METHOD}

The research method is done to examine the object of improvement of Arabic language teacher competency based on multiple intelligences classroom deeply. The researchers approach used a qualitative approach with case study methods. Data collection techniques are observation, interviews and documentation. Then checking the validity of the data is done by extension, participation, source triangulation technique, method triangulation and persistence of observation. The research informant is the student, the teacher and the principal.

During the data collection step, the researchers recorded the Arabic learning 
process. After that, the researchers reduced the data by selecting and sorting supporting data as this research report. Then, verified at this stage that the researchers have determined the main data as important data, and ignored the unwanted data.

\section{RESULT AND DISCUSSION}

Based on the direct observation results at SD Plus Al-Kautsar Malang, the researcher found the efforts to increase the competency of Arabic language teachers through the management classroom based on multiple intelligences, including the improvement of competency pedagogic and professional. The effort to increase pedagogic competence is realized through the training related to the creation of a lesson plan, while the effort to increase professional competence is realized through the training in applying multiple intelligence during the learning process, such as Multiple Intelligence System (MIS) and Multiple Intelligence Research (MIR) Training.

Efforts to increase pedagogic competence of teachers at SD Plus AlKautsar Malang is realized through the training related to the making of the lesson plan. A lesson plan is a plan made by the teacher before teaching. A common mistake that teachers make is to never create a learning plan first when it's teaching. The learning qualities of a teacher beginning with the creation of a learning plan will differ greatly from teachers who do not make prior learning plans. The advantage of teaching teachers using the lesson plan: 1) The teaching plan in the competency level is automatically recorded in the archives, 2) The archive of the Learning Plan will be the provision for the teachers concerned to use it as improvement In the following year, 3) the quality of the teachers will be controlled and recorded, 4) creation of professional learning process, 5) Teachers can measure the quality of learning in the class that relates to the results of students ' academic achievement, 6) give time for Teachers to analyse how a topic of learning is well presented and interesting

The pedagogic competence of teachers at SD Plus Al-Kautsar Malang has increased after having a management quality control in learning. The consequences of implementing management quality control are: 1) Lesson plan: Teachers must make planning learning, 2) Consultation: The teacher should discuss the study plan to the supervisor or consultant before teaching, 3) supervisor or Consultant observing directly the learning process in the classroom or in other environment, 4) Teachers ask supervisors or consultants to explain the results of observation of the learning process.

Based on the results of the interviews, researchers also found that the concept of multiple-based intelligences management at SD Plus Al-Kautsar Malang is an adaptive multiple intelligences-based learning process for education. The cornerstone of his thinking is that every human being has privileges. The principle of education: the digging of potential learners, the development of creativity and character reinforcement in harmony with meaningful education, meets the quality of the education standards developed.

A good management certainly has good planning anyway. Without planning, a manager can't know some of the risks and challenges that will be faced later. Basically, a planning is a sensible and structured activity that aims to establish decisions, activities, and steps that will be passed so that the objectives can be achieved effectively and efficiently (Mulyono, 2008:25). So, in a plan should use precise mapping so that the purpose of the creation of a program can be followed up to the maximum so that the desired objectives can be achieved.

Therefore, in the planning function will be encountered the following steps 
(Mulyono, 2008:26): (a) reach forward to estimate the circumstances and needs of the future, (b) determine the objectives to be achieved, (c) determine the policy that Pursued in relation to a pre-defined purpose, (d) Determining a programme, which includes the approach traveled, the type and sequence of activities, (e) Estimating the costs that constitute the thought amount of fees required, (f) determining the schedule and working procedures.

Several steps in the planning function above are closely related to class management. Classroom management is the process or effort undertaken by a teacher systematically to realize the dynamic and conducive classroom conditions in order to create effective and efficient learning, for the smooth learning management.

According to Usman Husaini (2008:3), teacher skills as a leader and manager in class, tasked with managing the physical environment of the class, conducive class climate, and the potential that learners have to always be enjoyable to Learning, resulting in a smooth learning management, and the creation of effective learners ' quality of learning outcomes.

The potential of the learners is closely related to the intelligence and learning style in the classroom. The potential of intelligence and the learning style of learners is very diverse. In the management of intelligence and learning style students in the classroom requires effective and efficient management to support the desired learning outcomes. To support the desired learning outcomes, there is a need to increase teachers competency and learning environment based on the type of intelligence and learning style owned by the learners (Hamzah B. Uno and Masri Kudrat: 2009:2).

Classroom management based on multiple intelligences are a form of classroom management that pays attention to the various intelligence and learning styles that students have in the classroom. In the implementation, classroom management based on multiple intelligences classifies learning environments or student classes based on the type of intelligence they possess. These class can make learners comfortable in the classroom, as they make it easy for learners to interact with friends who share the same type of intelligence in the classroom and maintain a learning style that is owned by learners. So, that the existence of learners who have the same type of intelligence can facilitate teachers in minimizing the problems encountered in the classroom, because the management class based on multiple intelligences is flexible and adapts with the background conditions of intelligence and learning style owned by learners (Mulyadi: 2009:4).

But empirically, there are still many teachers who lack understanding the application of classroom management based on multiple intelligences comprehensively, then it takes efforts to improve the competence of the Arabic teachers especially. So, it is unfortunate if the subject matter submitted by the teacher cannot be well received by the students because the barriers that occur are different types of intelligence and learning styles in the classroom, which are not teachers to manage learning environments in the classroom.

Classroom management is generally still mass, making students learn with the same types of intelligence and learning styles in the classroom. But they have different types of intelligence and learning that cannot be equated with other learners who have different types of intelligence and learning styles. Classroom management is less precise in the context of the students' opportunity to achieve maximum learning outcomes. To support the maximum student learning outcomes need to increase teachers' competency (Arabic language teachers) by developing a classroom management that pays attention and provides treatment to 
learners in accordance with intelligence and learning style owned (Hamzah B. Uno and Masri Kudrat: 2009:2).

Everyone has diversity and uniqueness of intelligence. Howard Gardner, (2003:97) an American research expert developed the "multiple intelligence" model of intelligence. Multiple intelligence means various intelligence. It says that everyone has an assortment of intelligence, but with different levels of development. What is meant by Gardner's intelligence is a collection of abilities or skills that can be developed. According to multiple intelligence theory in Jane \& $\mathrm{Ma}$ (2004:7) in each human self there are nine types of intelligence, namely: (1) intelligence of logicmathematical, (2) linguistic Intelligence, (3) musical Intelligence, (4) spatial intelligence, (5) bodily kinestetic intelligence, (6) intrapersonal intelligence, (7) interpersonal intelligence, (8) naturalist intelligence, and (9) existentialist intelligence.

SD Plus Al-Kautsar was established in 2004. The establishment of this school is based on two things, namely: 1) community needs of alternative schools of religion, 2) Animo from the guardian of students graduates TK B Plus Al- Kautsar for ongoing education. This was established by SD Plus AL-Kautsar. It is a formal education unit of the primary education level. SD Plus Al-Kautsar has a religious specificity, an integrated elementary education with Islamic nuance. Therefore, the presence of SD Plus Al- Kautsar is expected to answer the challenges of future HR needs that are faithful, intelligent, and cultured environment.

SD Plus Al-Kautsar was established in 2004, and was granted its operational permit from Malang City on 14 February 2004. The new school year begins on July 1 in 2004. The founding of SD Plus Al-Kautsar is the people of Pelita Hidayah Foundation. These people include the foundation, the leader of the foundation, the foundation Secretary and the Treasurer of the foundation. The chairman of Pelita Hidayah Foundation is Ir. Agus Suhardono, MT.

Based on the vision, mission and objectives of SD Plus Al-Kautsar are as follows: Vision of SD Plus Al-Kautsar Malang: "To be an ideal school to grow the people of Indonesia Islamic, intelligent, creative, caring and cultural environment". The Mission of SD Plus Al-Kautsar Malang: 1) preparing a superior generation who has competence in the field of IMTAQ (Iman and Taqwa) that is measured from the and science and technology that is measured by the way of thinking and scientific skills, 2) produce superior and competitive graduates in the affective, psychomotor and cognitive aspects, 3) to cultivate the noble values of the nation's culture, 4) guiding students to be healthy, active, creative and innovative human resources in accordance with the development of the Times, 5) Build a school image as a trusted educational institution in the community by providing a quality education, 6) build a comprehensive quality school system that includes input management, process and educational output, 7) to develop the culture of the school citizen in the protection efforts of the environment and natural resources, 8) to develop the culture of school citizens in the efforts to preserve the environment and natural resources.

The Objectives of the implementation of SD Plus Al-Kautsar Malang are: 1) educate students of faith and fear of Allah, love spiritual life and noble morality, healthy physically and spiritually, 2) develop all the individual potentials and uniqueness of the students optimal with the support of the synergy of the family, 3) provide provision for graduates to be ready to compete with the graduates of other education units, both in the sense of affective, psychomotor and cognitive, 4) transferring and transforming the sciences knowledge that students have the foundations of knowledge, mindset, and 
life skills to continue to a higher level of education and become a human being responsible for his lord, himself, his family, his people and His country, 5) instill a national patriotism and love of homeland, 6) instill a lifelong learning concept so that students can develop themselves and sustainably, 7) provide quality service community as a companion aspect in education, 8) the schools can make protection efforts on the environment and natural resources, 9) the schools can preservation efforts to the environment and natural resources, 10) the schools can efforts to prevent damage and pollution to the environment and natural resources.

SD Plus Al-Kautsar is a pioneer of the multiple intelligences school, organizing a child-friendly school, becoming a caring and cultured environmental school at the national independent level, as well as a quality school of national.

The specificity of the curriculum used is K-13 (national content, local content (Javanese language and culture), the content of school specificity (English, Arabic, ICT, and environment learning). Multiple Intelligences System (MIS) based on the class management system. This is related in the grouping of classes and learning processes, where learning methods are adapted to the student's learning style, thus affecting teacher teaching style in the learning process.

\section{CONCLUSION}

Based on the explanation above, the proposed conclusion is that the efforts to increase the competency of the teachers of
Arabic through the classroom management based on multiple intelligences at SD Plus Al-Kautsar Malang, including increased pedagogic competence and professional. The effort to increase pedagogic competence is given the training to educators related to the creation of a lesson plan, while the effort to increase professional competence is training in applying multiple intelligence during the learning process, such as multiple intelligence system (MIS) and multiple intelligence research (MIR) training.

\section{REFERENCES}

Badan Standar Nasional Pendidikan (BSNP). 2011.

Gardner, H. 2003. Multiple Intelligence. Batam: Interaksara.

Husaini, U. 2008. Management Theory of Practice and Research Education. Jakarta: Bumi Aksara.

Mulyadi. 2009. Classroom Management. Malang: UIN-Malang Press.

Mulyono. 2008. Administrative Management and Education Organization. Yogyakarta: Arruuz Media.

Sembiring, M. G. 2009. Reveal Secret and Effective Tips to Become a True Teacher. Yogyakarta: Galang Press.

Uno, H. B. \& Kudrat, M. 2009. Managing Intelligence in Learning. Jakarta: Bumi Aksara.

Zubaidah, S. 2016. 21 ${ }^{\text {st }}$ Century Skills: skills taught through learning. The National Seminar on Education "Strategic Learning Issues of MIPA 21st Century". 